\title{
Lumbar Disc Herniation in Fourteen Years Old Girl
}

\author{
Ondört Yaşındaki Kız Hastada Lumbar Disk Herniasyonu
}

\author{
Nalan CAPAN ${ }^{1}$, Sina ESMAEILZADEH ${ }^{1}$, Ceyhun BASOGLU ${ }^{1}$ \\ Mustafa CORUM ${ }^{1}$, Resa AYDIN ${ }^{1}$ \\ 1. Dept. of Physical Medicine and Rehabilitation, Istanbul University Istanbul Faculty of Medicine, Istanbul, Turkey
}

\section{ABSTRACT}

Lumbar disc herniation is a rare disease in children. Children and adolescents with symptomatic lumbar disc herniation have a history of trauma or sports injury before pain begins. There is no difference in the frequency of disc herniation between the gender in children. The segmental placement of disc herniation in children is similar to that seen in adults. A girl aged 14 years presented to our clinic complaining of a one-year low back pain and pain was radiating to the right leg. There was a significant posterocentral disc protrusion at the L5-SI level on magnetic resonance imaging (MRI). Complete symptomatic relief was achieved at the end of a course of conservative treatment.

Keywords: low back pain; children; disc herniation

\section{ÖZET}

Lomber disk hernisi çocuklarda nadir görülen bir hastalıktır. Çocuk ve adolesanlarda genellikle hikayelerinde ăgr başlangicindan önce travma ya da spor yaralanmaları öyküsü mevcuttur. Çocuklarda her iki cinsiyet arasında lomber disk hernisi sıklığl açısından fark saptanmamıştır. Segmental olarak disk herniasyonunun yeri açısından erişkin ve çocuklarda fark yoktur. Vakamızda 14 yaşında kız hasta bir yıldır olan bel ağrısı ve bacak ağrısı şikayetiyle kliniğimize başvurdu. Manyetik rezonans görüntülemede L5-S1 düzeyinde belirgin posterosantral disk protrüzyonu mevcuttu. Uygulanan konservatif tedavi sonrası ăgrllarında belirgin azalma elde edilmiştir.

Anahtar Kelimeler: sırt ă̆rısı; çocuk; disk herniasyonu

\section{Contact:}

Corresponding Author: Nalan Capan

Address: Istanbul University Istanbul Faculty of Medicine, Dept. of Physical Medicine and Rehabilitation, Millet Cad, Capa, Fatih, 34093, Istanbul, Turkiye

Phone: +90 (212) 4142000

E-mail: nalancapan@gmail.com

Submitted: 24.02 .2016

Accepted: 11.03 .2016

DOI: http://dx.doi.org/10.16948/zktb

\section{INTRODUCTION}

Lumbar disc herniations (LDH) is a rare disease in the pediatric population in contrast to the adult population. The etiology and clinical features may be different in children than in adults. The aim of treatment should be an early return to daily living activities and longterm effectiveness. There are multiple factors as potential causes, of which trauma is the most common etiologic factor in children, mostly through sports injury, heavy lifting, extreme flexion, extension, fall, etc. (1). As many as $30-60 \%$ of children and adolescents with symptomatic LDH have a history of trauma before the onset of pain (2).

However, there are reports in the literature that do not consider trauma the leading cause of lumbar pain in adolescents. Some studies have shown that one of the most likely factors that cause the early onset of lumbar disc herniation is vertebral deformities such as scoliosis, transitional defects (lumbarization and sacralization), spinal stenosis, and the presence of growth cartilage diseases such as Scheuermann's disease (3). The prevalence of symptomatic lumbar disc herniation in adolescents is between $0.5 \%$ and 3.8\% (4). It is more common in adolescents but can also be diagnosed due to fall in children aged less than two years (5). There is no clear sex difference in the frequency of lumbar disc herniation in children despite some researchers reporting a slight predominance in either sex in different studies $(6,8)$.

The symptoms of lumbar disc herniation are, motor or sensorial deficit, rarely, the findings like cauda equina syndrome and radiculopathy can be seen in adult patients. Children with these symptoms are often referred to departments such as orthopedics and neurology because other causes are suspected (7). In 52\% of children the segmental placement of lumbar disc herniation level is $\mathrm{L} 5 / \mathrm{S} 1$, the level is $\mathrm{L} 4 /$ L5 in $42.4 \%$, and the L3/L4 level is affected in $6.1 \%(9)$. This clinical situation is similar to that seen in adults. The abnormalities that may be associated with lumbar disc herniation include 
occult spina bifida, extra-lumbar vertebra, sacralization, spinal and lateral recess stenosis, and spondylolisthesis (10). The initial treatment of LDH in children is similar to that of adults unless LDH affects the patient's neurologic condition, in which case early surgical intervention must be performed (11).

\section{CASE}

History and presentation: A girl aged 14 years presented to our clinic with a one-year history of localized lower back pain (LBP) that radiated to her right leg. The patient reported daily discomfort, which was exacerbated with walking; she reported having to stop and sit. The pain did not disturb her sleep substantially. The only fall the patient could remember was an insignificant fall onto her buttocks from a wall when she was aged eight years; however, she was unable to recall if there was significant pain immediately after the fall. The patient was taking on average two to three non-steroidal antiinflammatories (NSAIDs) daily; however, despite the use of NSAIDs and her rest pain was still present. The patient had consulted the neurosurgery clinic and declined the recommended surgery and was subsequently referred to the physical medicine and rehabilitation clinic. Comprehensive physical rehabilitation program including the education of the patient was planned in Istanbul University Istanbul $\mathrm{Fa}$ culty of Medicine, Department of Physical Medicine and Rehabilitation inpatient clinic.

Examination: A physical examination showed that active lumbar range of motion (ROM) was painful and limited especially with anterior and lateral flexions. The patient had no significant scoliosis or lumbar antalgia while in a standing position. Her body mass index was 21.3. The patient was asked to rate her pain on a $10-\mathrm{cm}$ visual analog scale (VAS), 0 indicated no pain and 10 severe pain. VAS was evaluated at rest and active movement. The VAS was 4 and 8 at rest and with activity, respectively. The pain-free walking distance was 100 meters. The results of the neurologic examination, patellar and Achilles reflexes, motor strength and sensorial examination were unremarkable. The straight leg raise test (SLR) was positive at 40 degrees for the right lower limb and limited to 70 degrees bilaterally due to hamstring tightness. There was no difference in the leg length measurement. A brace was used in the first two weeks of treatment.

Imaging: There was a significant posterocentral disc protrusion at the L4-L5 and L5-S1 level on MRI (Figure 1,2). The results of the electromyography test were within normal limits.
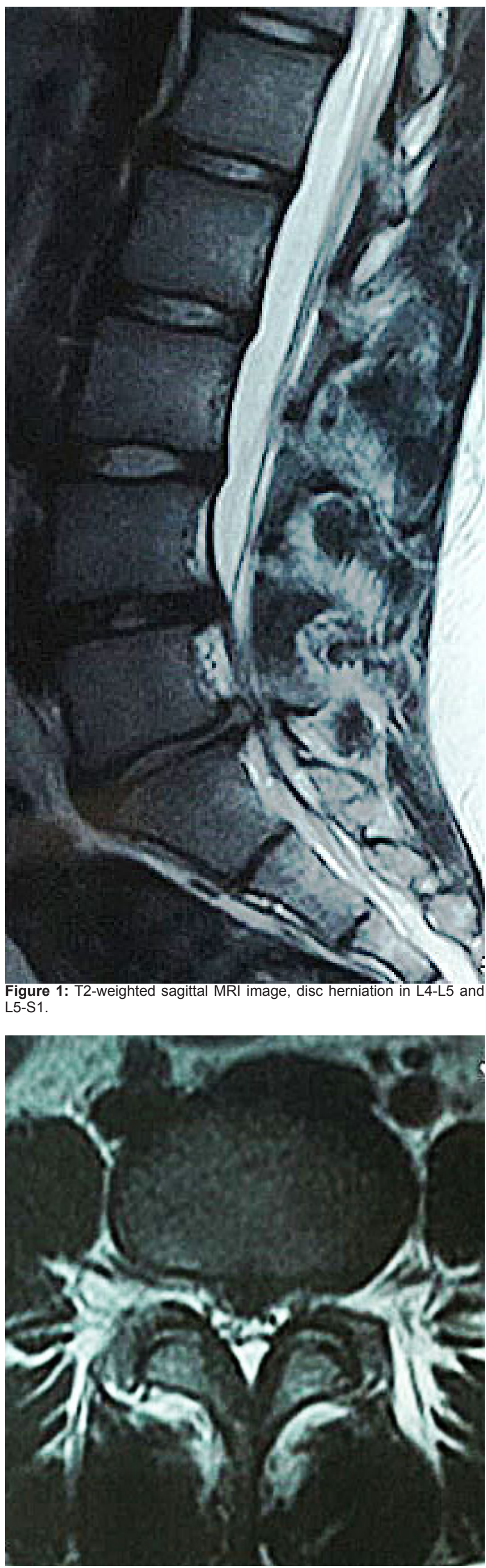

Figure 2: T2-weighted axial MRI image, santral disc herniation in L5-S1. 
Phvsical Therapv: The physical rehabilitation program included education and training of the patient in the 'back school' and exercises to help the patient keep her spine in a neutral position during all daily activities. Pelvic tilt exercises were given at the beginning of treatment with gentle stretching of the lumbar, gluteal and hamstring muscles. Exercises to strengthen the lower back and hip muscles were added to the program as the pain decreased. In addition, aerobic exercise such as walking on the treadmill at $3 \mathrm{~km} /$ hour for 15 minutes and dynamic lumbar stabilization were also prescribed. This program featured exercises that work the abdominal and back muscles to address posture, flexibility, and strength. Therapeutic ultrasound five minutes $1 \mathrm{watt} / \mathrm{cm}^{2}$, hot pack 30 minutes, and transcutaneus electrical nerve stimulation (TENS) 30 minutes in the lumbar paravertebral area were applied five times per week for three weeks. At the end of this treatment course, VAS at rest and activity were 0 and 2, respectively. The right SLR test was 80 degrees and the pain-free walking distance was 800 meters.

\section{DISCUSSION}

Back pain is common in healthy children and adolescents but lumbar disc herniation in the pediatric population is not common. The clinical signs of lumbar disc herniation in the pediatric population are not always similar to those of adults. Lumbar disc herniation in pediatrics may not cause radiating leg pain or signs of neurologic deficit. This can be explained because children and adolescents tend to have a greater nerve root tension than adults (12). Moreover, young patients are frequently unable to clearly explain their pain by themselves (7), which may cause a delay of diagnosis in children. The major features of adolescent lumbar disc herniation are a soft protruded disc, no severe spine degeneration, and typical discogenic pain, which are usually because of a single nerve root compression, with comparatively short symptom duration. It is often associated with back trauma and lumbar disc herniation sometimes appears together with a degenerative disease and bony spur formation like posterior Schmorl's node. (13) Sports-related activities and obesity may be a reason for lumbar disc herniation in the pediatric population. In previous studies the patient's family history, lumbar loading and strenuous physical exertion have also been shown to be risk factors for LDH (14). Moreover, neoplasm, infection (discitis and vertebral osteomyelitis), spondylolysis and spondylolisthesis, Scheuermann's disease, metabolic and systemic causes of back pain should be considered in the differential diagnosis for a young child who presents with low back pain $(15,16)$.
One of the most important tests performed in the diagnosis $\mathrm{LDH}$ is the straight leg raise test (SLR). The manual muscle test for motor strength and sensory examination should be performed. The deep tendon reflexes may be found to be diminished due to compression of the nerve root. When a disc herniation is suspected, the noninvasive and most useful option would be an MRI scan. MRI shows suspected herniated lumbar discs and allows for visualization of other pathologies such as epidural hematoma, fractures, and other nonsurgical etiologies. The L4/5 and L5/S1 discs are the most commonly affected in children, as it was in our patient, and there is usually more disc material herniated in children than in adults (17). Electrodiagnostic studies are also performed to diagnose lumbar disc herniation if radiculopathy is also present (18). Conservative treatment includes simple bed rest, using nonsteroidal antiinflammatory drugs, and physical therapy methods. The short- to long-term success rates of conservative treatment for pediatric $\mathrm{LDH}$ without neurologic deficits in the literature vary from $25-50 \%$. Kurth et al. compared outcomes of conservative treatment with surgical treatment for 33 pediatric patients (18 conservatively and 15 surgically treated cases) with a follow-up of 5.4 years and found no significance between the two groups (19). Additionally, Ippolito et al. emphasized the role of rehabilitation in juvenile lower back disorders (20). However, DeLuca et al. found that surgical treatment lead to a significantly better outcome than conservative treatment by carrying out a similar study on 31 pediatric patients ( 8 conservative, 23 surgical) with a 6-year follow-up period (21). Regardless of the controversy of our case, most authors are agreed that conservative treatment is not as effective for pediatric LDH as it is for adults. The reason for this may be 1) the disc of the pediatric is more hydrated and does not resorb like a degenerated adult disc 2) pediatric LDH is often associated with trauma where the annulus fibrosus could be severely ruptured and 3 ) children and adolescents are active and less likely to comply with strict therapy programs $(2,22)$. Surgery is necessary if there is severe refractory pain after 4 - 6 weeks of conservative treatment, progressive neurologic impairment, and cauda equina compression syndrome $(23,24)$. However, conservative treatment is still generally recommended as the first-line treatment for LDH in children and adolescents without neurologic deficits because iatrogenic deformities can develop after surgical intervention in the growing spine $(8,25,26)$. In conclusion, we emphasize the need to carefully evaluate low back pain in children and use comprehensive conservative treatment for first-line management. 


\section{REFERENCES}

1. Kazemi M. Adolescent lumbar disc herniation in a Tae Kwon Do martial artist: a case report. J Can Chiropr Assoc 1999;43(4):236-242.

2. Dang L, Liu Z. A review of current treatment for lumbar disc herniation in children and adolescents. Eur Spine J 2010;19(2):205-14.

3. Parisini P, Di Silvestre M, Greggi T, Miglietta A, Paderni S. Lumbar disc excision in children and adolescents. Spine (Phila Pa 1976) 2001;26(18):1997-2000.

4. Cahill J, Frost G, Solanki GA. Paediatric lumbar disc herniation in the very young: a case-based update. Childs Nerv Syst 2011;27(5):687-91.

5. Lavelle WF, Bianco A, Mason R, Betz RR, Albanese SA. Pediatric disk herniation. J Am Acad Orthop Surg 2011;19(11):649-56.

6. Martínez-Lage JF, Fernández Cornejo V, López F, Poza M. Lumbar disc herniation in early childhood: case report and literature review. Childs Nerv Syst 2003;19(4):258-60.

7. Revuelta R, De Juambelz PP, Fernandez B, Flores JA. Lumbar disc herniation in a 27-month-old child. Case report. J Neurosurg 2000;92(1 Suppl):98-100.

8. Slotkin JR, Mislow JM, Day AL, Proctor MR. Pediatric disk disease. Neurosurg Clin N Am 2007;18(4):659-67.

9. Frino J, McCarthy RE, Sparks CY, McCullough FL. Trends in adolescent lumbar disk herniation. J Pediatr Orthop 2006;26(5):579-81.

10. Haidar R, Ghanem I, Saad S, Uthman I. Lumbar disc herniation in young children. Acta Paediatr 2010;99(1):19-23.

11. Kuh SU, Kim YS, Cho YE, Yoon YS, Jin BH, Kim KS, Chin DK. Surgical treatments for lumbar disc disease in adolescent patients; chemonucleolysis / microsurgical discectomy/ PLIF with cages. Yonsei Med J 2005;46(1):125-32.

12. Matsui H, Kitagawa H, Kawaguchi Y, Tsuji H. Physiologic changes of nerve root during posterior lumbar discectomy. Spine 1995;20(6):654-9.

13. Wang H, Cheng J, Xiao H, Li C, Zhou Y. Adolescent lumbar disc herniation: experience from a large minimally invasive treatment centre for lumbar degenerative disease in Chongqing, China. Clin Neurol Neurosurg 2013;115(8):1415-9.
14. Zhang YG, Sun Z, Zhang Z, Liu J, Guo X. Risk factors for lumbar intervertebral disc herniation in Chinese population: a case-control study. Spine 2009;34(25):E91822.

15. Davis PJ, Williams HJ. The investigation and management of back pain in children. Arch Dis Child Educ Pract Ed 2008;93(3):73-83.

16. Benifla M, Melamed I, Barrelly R, Aloushin A, Shelef I. Unilateral partial hemilaminectomy for disc removal in a 1-year-old child. J Neurosurg Pediatr 2008;2(2):133-5.

17. Davis PJ, Williams HJ. The investigation and management of back pain in children. Arch Dis Child Educ Pract Ed 2008;93(3):73-83

18. Barr K. Electrodiagnosis of lumbar radiculopathy. Phys Med Rehabil Clin N Am 2013;24(1):79-91.

19. Kurth AA, Rau S, Wang C, Schmitt E. Treatment of lumbar disc herniation in the second decade of life. Eur Spine J 1996;5(4):220-4.

20. Ippolito E, Versari P, Lezzerini S. The role of rehabilitation in juvenile low back disorders. Pediatr Rehabil 2006;9(3):174-84.

21. DeLuca PF, Mason DE, Weiand R, Howard R, Bassett GS. Excision of herniated nucleus pulposus in children and adolescents. J Pediatr Orthop 1994;14(3):318-22.

22. Kumar R, Kumar V, Das NK, Behari S, Mahapatra AK. Adolescent lumbar disc disease: findings and outcome. Childs Nerv Syst 2007;23(11):1295-9.

23. Kotil K, Akçetin M, Bilge T. Cauda equina compression syndrome in a child due to lumbar disc herniation. Childs Nerv Syst 2004;20(6):443-4.

24. Jiang SD, Jiang LS, Dai LY. Extreme lateral lumbar disc herniation in a 12-year child: case report and review of the literature. Eur Spine J 2010;19 Suppl 2:S197-9.

25. Ozgen S, Konya D, Toktas OZ, Dagcinar A, Ozek MM. Lumbar disc herniation in adolescence. Pediatr Neurosurg 2007;43(2):77-81.

26. Kuh SU, Kim YS, Cho YE, Yoon YS, Jin BH, Kim KS, Chin DK. Surgical treatments for lumbar disc disease in adolescent patients; chemonucleolysis / microsurgical discectomy/ PLIF with cages. Yonsei Med J 2005;46(1):125-32.

27. Çelik S, Göksu K, Çelik SE, Emir CB. Benign neurological recovery with low recurrence and low peridural fibrosis rate in pediatric disc herniations after lumbar microdiscectomy. Pediatr Neurosurg 2011;47(6):417-22. 